У,AK 1(100) (091):378

ББК $87.3(0)+74.58$

DOI 10.22394/1682-2358-2018-4-122-128

V.N. Gasilin, Honorary Figure of Russian Higher Education, Doctor of Sciences (Philosophy), Professor of the Philosophy Department, Povolzbsky Institute of Management named after P.A. Stolypin, Branch of the Russian Presidential Academy of National Economy and Public Administration

L.Ya. Sakseltseva, Candidate of Sciences (Philosophy), Docent of the Sociology and Social Policy Department, Povolzbsky Institute of Management named after P.A. Stolypin, Branch of the Russian Presidential Academy of National Economy and Public Administration

\section{PREPARATION OF PHILOSOPHICAL STAFF IN THE USSR IN THE 1920S}

The process of formation of the Institute for the preparation of philosophical stuff in the USSR in the 1920s during the formation of Marxist philosophy is analyzed. Data on the first teachers of the Institute of Red Professors and their role in the development of Marxism-Leninism philosophy are given.

Key words and word-combinations: Institute of Red Professors, M.N. Pokrovsky, N.I. Bukharin, E.M. Yaroslavsky, V.I. Nevsky, A.V. Lunacharsky.
B.Н. Гасилин, заслуженньй работник висшей школь РФ, доктор философских наук профессор кафедри философии Поволжского института упраһления имени П.А. Стольппина - филиала Российской академии народного хозяйства и государственной служби при Президенте РФ (email:v.gasilin@yandex.ru).

1.Я. Саксельиева, кандидат философских наук, дочент кафедри сочиологи и сочиальной политики Поволжского института управления имени П.А. Стольгпина - филиала Российской академии народного хозяйства и государственной служби при Президенте РФ (email: sl955@list.ru)

\section{ПОАГОТОВКА ФИАОСОФСКИХ КААРОВ В СССР В 20-Е ГОАЫ ХХ ВЕКА}

\footnotetext{
Аннотация. Анализируется процесс становления института подготовки философских кадров в СССР в 20-е годы XX века, в период формирования марксистской философии. Приведены данные о первых преподавателях Института красной профессуры и их роли в разработке марксистсколенинского учения.

Ключевые слова и словосочетания: Институт красной профессуры, М.Н. Покровский, Н.И. Бухарин, Е.М. Ярославский, В.И. Невский, А.В. Луначарский.

B последние годы актуальным становится обращение к истории становмения общественных институтов, сопровождавшейся идейно-теоретическими и политическими разногласиями в советском обществе 20-х годов ХХ в. Это касается и института
} 
подготовки фимософских кадров, где развернулась борьба между сторонниками марксистского и немарксистского направлений в философии. Размежевание тех и других проходияо по «кАассовому», а точнее, идеологическому принџипу. Страна, в которой после революции победияа единственно «истинная» идеомогия марксизма, должна была отмежеваться от всего чуждого, в том числе в философии. Вопрос касался не только создания новой идеологии, но и организации подготовки философских кадров, которые должны были стать активными пропагандистами марксистских идей как в системе образования, так и в обществе в целом. Первая задача достаточно «успешно» была решена властями к 1924 г., в том числе высылкой оппонентов за пределы страны. Аругая задача состояла в создании системы подготовки идеологически выдержанных партийных и философских кадров, которых катастрофически не хватало.

С приходом советской власти в области философии произошли радикальные перемены. Поставленная большевиками задача создания «нового общества» требовала подготовки покомения соџиальных теоретиков в русле марксистской идеологии, которые проводили бы минию партии в науке и преподавании. С этой цемью в 1918 г. была создана Коммунистическая академия, в состав которой входиц Институт философии. В 1919 г. учрежден Коммунистический университет имени Свердмова дмя подготовки партийных кадров, а также сформированы Аругие вузы «соџиалистической ориентации». Поскольку «буржуазные» профессора с дореволюџионным стажем явно не годились ААя такой миссии, власть пыталась в кратчайший срок выковать новые ангажированные кадры «красных профессоров». ОАним из таких экспериментальных проектов стал Институт красной профессуры, важнейший центр ускоренной подготовки научных, преподавательских и управленческих кадров (1921-1938).

В соответствии с постановлением Совета народных комиссаров РСФСР от 11 февраля 1921 г. в Москве и Петрограде были учреждены институты по подготовке красной профессуры для преподавания в высших школах таких дисциплин, как теоретическая экономия, исторический материализм, развитие обшественных форм, новейшая история и советское строительство [1, с. 72] . Из-за нехватки преподавательских кадров институт функционировац только в Москве. Первый выпуск состоялся в 1924 г. За пять выпусков (1924-1928) бымо подготовмено 194 слушатемя [2, с. 86].

Аля решения каАровой проблемы в Институте красной профессуры (ИКП) потребовалась особая директива ВКП(б), постановившая освободить партийных теоретиков от работы, «где они не явмяются абсолютно незаменимыми». Из-за нехватки мекторов приходилось даже отчислять студентов без права восстановления, а к преподаванию привлекать слушателей старших курсов. Первыми студентами ИКП стали демобилизованные сомдаты Красной Армии, где велась активная идеологическая пропаганда. В институте учились и бывшие слушатели дореволюџионных вузов, и миџа, желавшие заняться самообразованием. К приемным экзаменам допускались миџа, направленные ЦК или обкомом партии, как правило, с высшим образованием. Вначаме принимали и беспартийных студентов, но к 1922 г. был необходим уже двухлетний партийный стаж, затем - трехлетний, к 1924 г. - пятиметний, а к 1929 г. на определенных отделениях требовалось до 8 и 10 мет стажа. 
В 1920-е годы основным источником комплектования Института красной профессуры стали выпускники Коммунистического университета имени Я.М. Свердлова. В числе слушателей были и работающие преподаватели, и партийные работники, занимавшие до поступления ответственные посты (секретари райкомов, губкомов, заведующие районными агитпропами и мр.) [3, с. 421, 415]. Задача численного преобладания абитуриентов-прометариев в ИКП была ключевой, невзирая на ущерб качеству их подготовки. В соответствии с политикой советской власти рабоче-крестьянская интемлигенџия, сформированная выпускниками коммунистических вузов, должна была вытеснить «буржкуазную». Вопрос соџиального происхождения представмял первостепенную важность согласно буквально понятой материалистической теорией К. Маркса: бытие опредемяет сознание. Аекларируемая необходимость «подтягивания» образовательного уровня рабоче-крестьянских масс на деле оборачивалась стиранием границ между образованными и необразованными.

В 1921 г. В.И. Аенин в «Правде» писал: «...Соержкание обучения, поскольку речь идет об общеобразовательных предметах, в особенности же о философии, общественных науках и коммунистическом воспитании, должно опредемяться только коммунистами» [4]. Это означало жесткую идеологическую регламентацию учебного процесса. Идеология насаждалась не только «сверху», на учебный процесс влияли и студенты-коммунисты: они участвовали в формировании учебных курсов и даже могли снять преподавателя с должности. Разумеется, такая студенческая вольница нередко вредила обучению, которое Алимось три, иногАа четыре года. С момента зачисления студентов автоматически принимали на Аолжности в ЦК ВКП(б).

Особое место занимала подготовка преподавателей философии, которая в советский период понималась как универсальная дисциплина: материалистическая диалектика стала единственно верной методологией цюбых наук, естественных и гуманитарных. Переинтерпретированная советскими фимософами марксистская идеология отныне должна была пронизывать все сферы жизни общества. Философия все более политизировалась, в ней использовамись, причем достаточно произвольно, политические термины Амя обвинения оппонентов, полным ходом шла «большевизация философского фронта», что на деме означало зачистку философского поля от самостоятельно мыслящих философов и их школ.

В числе первых преподавателей института, а потом и академии присутствовали как партийные профессора (Н.И. Бухарин, М.Н. Покровский, В.И. Невский, А.В. Ауначарский, Е.И. Ярославский, А.М. Аукин и Ар.), так и беспартийные, активные меньшевики (В.А. Базаров, А.Б. Савин, Е.В. Тарме, Б.А. Греков, П.Б. Струве, А.М. Аеборин). Периодически с докмадами выступали Сталин, А.А. Троџкий, Г.А. Зиновьев, А.М. Каганович, М.И. Калинин и ар.) $[5$, с. 469].

Чтобы преАставить ситуаџию более всесторонне, подробнее ознакомимся с кадровым составом преподавателей ИКП.

М.Н. Покровский руководиц институтом в 1921-1931 гг., историк, соџиолог, государственный деятель. Окончил историко-фимологический факультет 
Московского университета. Был председателем Президиума Соџиалистической (с 1924 г. - Коммунистической) академии. С 1929 г. являлся директором Института истории. В 1920-х годах содействовал установлению тесных связей философов и естествоиспытателей [6]. Н.И. Бухарин называл его «профессором с пикой» за непримиримость к оппонентам. После смерти М.Н. Покровского в связи с происходившей масштабной кампанией по пересмотру идеологии его взгляды были объявлены «антимарксистскими», антипатриотичными; его школа была разгромлена, а труды изъяты из библиотек.

Н.И. Бухарин активно занимался преподавательской деятельностью: работал в Институте красной профессуры, Коммунистической академии, а также в институте К. Маркса и Ф. Энгельса. С 1929 г. Н.И. Бухарин - академик АН СССР. К 1920 г. он отошел от традиџионного марксистского понимания того, что социализм вырастает в неАрах капитализма (видимо, четко представляя отсталость России), стал сторонником революционного насилия - принуждения в качестве метода выработки коммунистического человечества из человеческого материала современной эпохи. Вместе с тем в отличие от традиционного марксизма он предлагал новые трактовки ряда категорий. Впервые разграничив понятия «надстройка» и «идеология», которые большинством марксистов того времени отождествцялись, исследовац многообразие опосредований базисных отношений надстроечными; ввел понятие материальной культуры. Многие положения трудов Н.И. Бухарина (в частности, понимание «органического» и «механистического» и Ар.) стали предметом Аискуссий 1920-х годов. Как отмечают исследователи, Н.И. Бухарин не принял распространившихся в это время версий ни об исключительно политической ориентации менинского творчества, противопоставцявших Аенина-теоретика Аенину-практику, ни об отождествлении марксизма и менинизма. Аля него Аенин был мыслителем крупнейшей интемлектуальной симы нового типа [7, с. 373-374].

E.M. Ярославский - активный сторонник Сталина, один их тех, кто активно формировац культ его цичности. Он автор значительного числа работ, большинство из которых носят антирелигиозный характер. Н.С. Хрушев вспоминац, что в партии Е.М. Ярославского называци «советским попом», так как в 1920-1930-е гг. он явмялся главным авторитетом партии по «церковному вопросу» и инициатором атеистической политики советского руководства. В его оголтелой «критике» религии использовались самые грязные технологии, без оглядки на религиозные чувства верующих. Е.М. Ярославский запустил известный мозунг: «Борьба против религии - борьба за соџиализм» имевший целью утвердить научный атеизм. О подлинной научности речь, разумеется, не шка. В конџе 1920-х годов он выступил против исполнения џерковной музыки, в том чисме П.И. Чайковского, С.В. Рахманинова, И.С. Моџарта, И.С. Баха, Г.Ф. Гендемя. «В данный момент, - писал он, - церковная музыка, хотя бы и в ее кучших произведениях, имеет актуально-реакщионное значение» [8] . При участии Е.М. Ярославского составцялись списки запрешенных книг, в которые вошли произведения Пцатона, Канта, Вц. Соловьева, А.Н. Тоцстого, Ф.М. Аостоевского. Чем не максимализм средневековой инквизиции! ПоА все это подводимось «теоретическое обоснование», например: «Толстой в настоящее время, если 
брать его отрицательное отношение к государству, если взять его отрицательное отношение к классовой борьбе, его враждебность к науке, является выразителем идей и настроений социальных прослоек, не имеющих никакого будущего, политическое значение которых ААя сегодняшнего Аня ничтожно» [8] .

Видный большевистский руководитель В.И. Невский также работал преподавателем института. В первой половине 1920-х годов он выступал как критик философских и мировоззренческих проблем с позиџий марксизма. Характер критики в основном был дружественный, нацеменный на привлечение к совместной работе с фицософами-немарксистами. Вот что он писал об известном отечественном ученом-физиологе И.П. Павлове: «Мы хотим обратить внимание всех интересующихся и изучающих философию, материалистов в особенности, какое богатство материала, мыслей и имлюстраџий к теории материалистического миропонимания находишь в интересных работах И.П. Павцова. Пускай сам И.П. Павлов не декает никаких фимософских выводов (он тысячу раз прав в этом), пускай некоторые ученики его держатся кантианских взглядов, огромное значение работ Павлова бесспорно» [9, с. 147]. Вместе с тем большинство выступлений В.И. Невского, касающихся философов немарксистской ориентации, отличалось нетерпимостью и политизированностью. В области обшественных и философских дисџиплин, утвержаал он, «ныне господствует исключительно тяга к самым отАаленным истокам теологии. И за что бы ни брался современный буржуазный ученый, за философию, историю, психологию, этику - он, в конечном счете, прихоАит к Господу Богу». Он отождествлял идеализм с религией и непосреАственно связывал их с политической реакџией. «Гибелью, тмением, средневековым мракобесием веет ныне от буржуазной философской мысли. Философия мертвой реакции - вот как можно назвать все писания буржуазных фимософов нашего времени» $[10$, с. 98]. И это писалось в то время, когда творили такие выдающиеся философы ХХ в. как Э. Гуссерль, М. Хайдеггер, О. Шпенглер, Б. Рассел, Х. Ортега-и-Гассет и многие Аругие.

Особняком в ряду этих марксистских пропагандистов от философии стоял А.В. Ауначарский - писатель, общественный и политический деятель, публицист, искусствовеА, философ, культуролог. У этого настоящего интемлигента была иная судьба. В начале ХХ в. он оказался под вциянием А.А. Богданова, врача, энциклопедиста и деятеля мевого движения, на сестре Анне которого женился. В 1895 г. А.В. Ауначарский поступает в университет в Цюрихе; много читает, слушает кекџии Р. Авенариуса, увлекается эмпириокритиџизмом, не совместимым с марксизмом. В это время он вступил в масонскую можу, пытаясь постичь суть тайных знаний и вместе с тем становится убежденным атеистом. Он увидел в марксизме не веру в Бога, а веру без Бога.

В.И. Аенин подвергал Ауначарского критике за «богостроительство» - направление философско-этической мысли, возникшее в среде русских марксистских китераторов в первом десятилетии XX в. Его представители рассматривали всеобщую созидательную деятельность человечества как религию. У богостроителей было два мидера - М. Горький (в этот период он написал «ИсповеАь, 1908) и А.В. Ауначарский, который видел в теории научного социализма «пятую великую религию, сформулированную иудейством» [11] . 
На наш взгляА, недопустимо представмять марксизм и его философию в качестве религии, как это демал А.В. Ауначарский, особенно если исходить из понимания религии как веры в сверхъестественное; отсюда и оговорка: религия без Бога. ОАнако называть религию без Бога атеизмом тожке некорректно; будАизм, строго говоря, это тоже религия без Бога, поскольку БудАа не является Богом. Аругое Аело, что в 1920-1930-е годы марксизм насаждался в СССР (особенно в области обрядов, ритуалов) как идеология, сходная с религиозной.

А.В. Ауначарский был талантмивым кектором, его выступцения отличались популярным, достаточно упрошенным изцожением материализма и идеализма, поскольку его слушателями была в основном молодежь, не искушенная в философской терминологии. В мекщиях при трактовке фимософии и рекигии преобладал кмассовый подход.

В. Рожиџын в 1921 г. Аал достаточно верную «оценку» философским каАрам того времени: «Их четверо - Пцеханов, Аксельрод, Аеборин и Аенин» [12, с. 410]. Г.В. Пиеханов умер в 1918 г., будучи меньшевиком, к тому же отнесшимся к Октябрьской революџии крайне отрицательно, видел в ней «нарушение всех исторических законов»; Ценин, будучи главой государства, вряд ми смог бы читать мекции. Остаются - А.М. Аеборин и П.И. Аксельрод; оба - профессиональные философы, получившие ученую степень за рубежом.

В 1921 г. Коммунистический университет имени Я.М. Свердмова ходатайствовал о привлечении П.И. Аксельрода и А.М. Аеборина к чтению мекций. Оргбюро решило этот вопрос отрицательно. В связи с этим Е.М. Ярославский, бывший в то время секретарем ЦК РКП(б), обратияся 20 апреля 1921 г. к Аенину с письмом: «Считаете ми вы возможным привлечение к чтению мекций по философии (история философии, исторический материализм) Аеборина и Аксельрода? Об этом запрашивал ученый совет университета Свердлова. Мы на оргбюро вопрос об Аксельроде решили отрицательно, но теперь он возбужАается вновь цекторской группой». Аенин в тот же день ответил: «По-моему, обязательно привлечь обоих. Полезно, ибо они будут отстаивать марксизм (если станут агитировать за меньшевизм, мы их поймаем: присмотреть надо). Их бы обоих привлечь к выработке детальнейшей программы (и конспекта мекций) по фимософии и плана изданий по фимософии» [13] .

Таким образом, советская власть, нуждаясь в профессиональных кадрах пропагандистов своей идеологии, использовала квалифицированных специамистов иных взглядов во всех областях, в том числе и в философии. Их инте мект и знания привлекамись Амя формирования пропагандистских каАров и продвижения марксистской идеологии поА своим «присмотром». Слушатели института активно публиковались, участвовали в научных дискуссиях и конференциях. Обязательной частью учебного процесса была партийная деятельность (преподавание в партшколах, ведение агитационно-пропагандистской работы, работа на предприятиях секретарями партийных ячеек коммунистов и т.А.) и педагогическая практика (ведение курсов по своей специальности в вузах и на рабфаках). Слушатели ИКП со второго курса обязаны были вести пеАагогическую работу при том или ином вузе. 
Некоторое время в Советском Союзе практикованось присвоение профессорского звания посме окончания Института красной профессуры; во второй половине 1930-х годов правила представления к званию ужесточились. Со второй половины 1920-х годов слушатели института по-разному проявмяли себя в борьбе с оппозиционными течениями в ВКП(б).

Посме шестнадџати мет существования Институт красной профессуры киквидировался в спешке, посреди учебного года и практически задним числом. Причины закрытия не до конца ясны. Официальная формулировка выглядит так: «Признано нецелесообразным дальнейшее существование институтов красной профессуры в связи с тем, что высшие учебные заведения и аспирантура при них могут полностью разрешать задачи, стоявшие ранее переА ИКП в области подготовки преподавательских кадров» [14] .

Итак, рассмотренный относительно небольшой период становления института подготовки философских кадров, проходивший в условиях острой политической и идейной борьбы сторонников разных философских направлений, положил начало полной победе марксистской фимософии на долгие десятилетия.

\section{Библиографический список}

1. Собрание узаконений и распоряжений Рабочего и Крестьянского правительства РСФСР. 1921. № 12.

2. Исторический архив. 1958. № 6.

3. Никулинкова E.B. Институт красной профессуры: структура и организация учебного процесса (1921-1930 гг.) // Петербургская историческая школа. Третий год выпуска. Памяти Е.Р. Ольховского. СПб., 2004.

4. URL: https://www.runivers.ru/philosophy/chronograph/476505/

5. Философы России XIX-XX столетий: Биографии, идеи, труды. 2-е изд., перераб. и доп. M., 1995.

6. Покровский М.Н. Избранные сочинения. М., 1965-1967. T. 1-4. URL: http://megabook. $\mathrm{ru} /$ article $/ \% \mathrm{D} 0 \% 9 \mathrm{~F} \% \mathrm{D} 0 \mathrm{BE} \% \mathrm{BA} \% \mathrm{D} 1 \% 80$

7. Бухарин Н.И. Автобиография // Деятели СССР и революционного движения в России: энциклопедический словарь. М., 1989.

8. Ярославский E.M. Можно ли прожить без веры в Бога? М., 1926 // На переломе: Философские дискуссии 20-х годов: Философия и мировоззрение / сост. П.В. Алексеев. М., 1990. C. $373-380$.

9. Невский В.И. Современное естествознание и материализм Маркса и Энгельса // Под знаменем марксизма. 1923. № 2/3.

10. Невский В.И. Нострадамусы ХХ века // Под знаменем марксизма. 1922. № 4.

11. Луначарский А.В. Человек Нового Мира. М., 1980.

12. Алексеев П.В. Философы России XIX-XX столетий: биографии, идеи, труды. М., 2002.

13. Коган Л.А. На подступах к советской философии (первые «свердловцы», социалистические академики», «икаписты») // Вопросы философии». 2002. № 5. С. 112-140.

14. ГАРФ. Ф. 3316. Оп. 12. Д. 848. Л. 2. 